\title{
Kaya Kütlesi Deformasyon Modülünün Farklı Yöntemlerle Belirlenmesi
}

\section{Determination of Rock Mass Deformation Modulus by Different Methods}

\section{KADIR KARAMAN ${ }^{1 *}$, FERDi CIHANGIR ${ }^{1}$, SERKAN DEMIREL ${ }^{2}$, AYHAN KESIMAL ${ }^{1}$}

${ }^{1}$ Karadeniz Teknik Üniversitesi Maden Müh. Bölümü, Trabzon

${ }^{2}$ NVS İnş. San. ve Tic. Ltd. Şti., Trabzon

Geliș (received) : 05 Mayıs (May) 2014

Kabul (accepted) : 11 Aralık (December) 2014

\section{öz}

Birçok tasarım parametresi arasında kaya kütlelerinin yerinde deformasyon modülü $\left(\mathrm{E}_{\mathrm{m}}\right)$ kaya mühendisliği projelerinin bașarıyla yürütülmesinde ve tasarımında hayati öneme sahip olan önemli bir parametredir. Ancak, yerinde testler zaman alıcı ve pahalı hatta bazı durumlarda yapılması imkânsız olabilmektedir. Bu sınıllandırmalar, araștırmacıları deformasyon modülünü daha düșük fiyatla kolay bir șekilde diğer kaya kütle özelliklerine (RQD, RMR, Q) dayanarak dolaylı olarak tahmininde ampirik eșitlik geliștirmesine zorlamıștır. Bu çalıșmada da kaya kütleleri için ampirik bir eșitlik önerilmiștir. Bu amaca yönelik olarak, bir tünel güzergâhının otuz yedi farklı noktasındaki volkanik, tortul ve metamorfik kaya kütleleri üzerinde çalıșıııștır. Karșılaștırmak amacıyla, literatürde önerilmiș olan altı farklı ampirik eșitlik yardımıyla $E_{m}$ değerleri hesaplanmıștır. Çoklu karșılaștırma ANOVA testleri ayrıca önerilen ve diğer eșitlikler arasında yapılmıștır. ANOVA analizleri bu çalıșmada üretilen eșitliğin kaya kütlelerinin $\mathrm{E}_{\mathrm{m}}$ değerlerinin belirlenmesinde güvenle kullanılabileceğini göstermiștir.

Anahtar Kelimeler: Deformasyon modülü, nokta yükleme indeksi, RMR, RQD, Q

\begin{abstract}
Among the many design properties, the deformation modulus $\left(E_{m}\right)$ of in-situ rock mass is a crucial parameter and has a vital importance for the design and successful execution of rock engineering projects. However, in-situ tests are time-consuming, expensive and, in some cases, even impossible to carry out. This constraint forced the investigators to develop an empirical equation for indirect estimation of the deformation modulus of rock masses based on other rock mass properties that can be easily determined at low cost such as $R Q D, R M R$, $Q$, etc. In this study an empirical equation was proposed for tested rock masses. For these purposes, volcanic, sedimentary and metamorphic rock masses were studied at different thirty seven points along a tunnel alignment. For comparison, $E_{m}$ was calculated from six other empirical equations recommended in the literature. Multiple comparison tests (ANOVA) were also performed among the new relation and other empirical equations. Based on the ANOVA analyses, the $E_{m}$ of a rock mass can be estimated from the proposed equation reliably.
\end{abstract}

Keywords: Deformation modulus, point load index, $R M R, R Q D, Q$

\footnotetext{
${ }^{*}$ K. Karaman

e-posta: kadirkaraman@ktu.edu.tr
} 


\section{GiRiș}

Yeryüzünde çeșitli amaçlara yönelik olarak tasarlanan büyük mühendislik yapılarının yanı sıra, gelișmiș ve gelișmekte olan ülkelerde giderek artmakta olan enerji, ulașım, yerleșim ve alt yapı gibi gereksinimlerin karșılanabilmesi için yeraltı yapıları da hızla çoğalmakta ve boyut olarak büyümektedir. Ancak, baraj, tünel, köprü ayağı, bina vb. gibi mühendislik proje çalıșmaları incelendiğinde tünel inșaatlarında diğerlerine oranla bilinmeyenlerin sayısı oldukça fazladır. Bu nedenle araștırmacılar, çeșitli araștırma yöntemlerinden yararlanarak bu bilinmeyenlerin sayısını asgariye indirmeye çalıșmaktadırlar.

Görgül (kaya kütlesi sınıflama sistemleri) ve sayısal yöntemler tünel gibi yeraltı mühendislik yapılarının tasarlanmasında yaygın olarak kullanılan iki önemli araçtır. Günümüzde açılmakta olan tünellerin birçoğunda kaya kütlesi sınıflama sistemlerinden yararlanılmaktadır. Bu sistemler, yaklașık 70 yıl öncesinden (Terzaghi, 1946) bașlayarak günümüze kadar geliștirilmiș, buna paralel olarak ortaya birçok yeni sınıflama sistemleri konmuș ve çeșitli projelerde uygulanmıștır. Kaya kütlesi sınıflama sistemlerinden Kaya Kütle Puanlaması (RMR) ve Kaya Kütle Kalitesi (Q), bir çok araștırmacı tarafından yüzlerce tünelde bașarı ile uygulanmıș ve evrensel düzeyde kabul görmüștür (Bieniawski, 1973; Barton vd., 1974; Bieniawski, 1989; Barton, 2002; Ramamurthy, 2004; Sarı ve Pașamehmetoğlu, 2004; Basarir vd., 2005; Gürocak, 2011; Kaya vd., 2011). Bu sistemler, tünellerin daha ekonomik, daha az riskle ve daha kısa sürede açılmasına büyük ölçüde katkıda bulunmaktadır. Ancak, kaya kütlesi sınıflama sistemleri tünellerin ilk inșa așaması süresince çok kullanıșlı olmasına rağmen, bu sistemler, tünel etrafındaki gerilme dağıımlarını, destek performansını ve deformasyonunun hesaplanmasını sağlamamaktadır (Geniș vd., 2007). Yeraltı projelerinin daha ekonomik ve emniyetli bir șekilde yürütülebilmesi, sayısal analizlerin görgül yöntemlerle birlikte değerlendirilmesiyle gerçekleşmektedir.

Sayısal analizlerin girdi parametrelerinden biri kaya kütlelerinin deformasyon modülü ( $\left.E_{m}\right)$ ' dür. $E_{m}$, kaya kütlesinin yenilme öncesindeki mekanik davranıșını en iyi temsil eden bir parametre olmasından dolayı, birçok tasarım parametresi arasında kaya mühendislik projelerinin bașarıyla gerçekleștirilmesinde çok önemli bir yere sahiptir. $\mathrm{E}_{\mathrm{m}}$ ayrıca yeraltı açıklığı etrafında izlenen deformasyonların yorumlanmasında, tahkimat ve nihai tünel kaplama tasarımında kullanılmaktadır (Hoek ve Diederichs, 2006). Ancak bu parametrenin arazide tayini hem çok zor hem de pahalıdır (Aksoy vd., 2012). Ayrıca, arazide yapılan deneyler, kaya kütlelerinin deformasyonları hakkında doğrudan bilgi vermesine karșın, Bieniawski (1973) tarafından belirtildiği gibi yerinde yapılan testlere tek bașına güvenilmemesi gerektiği ifade edilmiștir (Shen vd., 2012). Palmström ve Singh (2001) ise yerinde yapılan deneylerin ekipmandan ve patlatma etkisinden dolayı ölçüm hatalarına yol açtığı, bu nedenle kaya kütlelerinin iyi bir șekilde değerlendirilmesi ve uygun dolaylı yöntemin/eșitliğin birçok durumda yerinde deneylere göre daha iyi sonuçlar verdiğini belirtmișlerdir. Bu nedenle, $E_{m}$ parametresinin pratik yoldan tahminine yönelik literatürde araștırmacılar tarafından bir çok ampirik eșitlikler önerilmiștir (Bieniawski, 1978; Serafim ve Pereira, 1983; Aydan vd., 1997; Hoek ve Brown, 1997; Read vd., 1999; Palmström ve Singh, 2001; Barton, 2002; Zhang ve Einstein, 2004). Bazı araștırmacılar da (Hashemi vd., 2010; Shen vd., 2012; Aksoy vd., 2012; Khabbazi vd., 2013) literatürde $E_{m}$ tahmini için önerilen eșitlikleri kendi bulgularıyla kıyaslamıșlardır. Gürocak (2011) ise farklı ampirik eşitlikler ile (9-10 eşitlik) tahmin ettiği $\mathrm{E}_{m}$ değerlerinin ortalamasını alarak sayısal analizlerde kullanmıștır.

$\mathrm{E}_{\mathrm{m}}$ tahminine yönelik eșitliklerin olușturulmasında çoğunlukla kaya kütlesi sınıflama sistemlerinden daha az oranda da indeks deneylerden yararlanılmıștır. Örneğin RMR'den elde edilen eșitlikler birçok araștırmacı tarafından kullanıımıș ve $\mathrm{E}_{m}$ tahmininde güvenilirliği konusunda övgü ile bahsedilmiștir (Nejati vd., 2014). Palmström ve Singh (2001) $E_{m}$ tahmininde en sık RMR sisteminin kullanıldığını ifade etmișlerdir. Khabbazi vd. (2013) test edilen parametreler (tek eksenli basınç dayanımı, ultrasonik dalga hızı) arasında deformasyon modülü ile en iyi ilișkiyi RMR verdiğini belirtmișlerdir. Ancak özellikle güzergâh belirleme çalıșmalarında ve projelerin ilk așamasında kaya kütlelerinden temsili örnek almada 
yașanan güçlüklerden veya problemli kaya ortamlarından (piroklastik, sık eklemli, vb.) dolayı RMR sınıflamasında ve bazı $E_{m}$ eşitliklerinde kullanılan tek eksenli basınç dayanımı (UCS) gibi yüksek kaliteli karot gerektiren deneylerin yapılması mümkün olmamaktadır (Kaya, 2012; Karaman ve Kesimal, 2013). Bu çalıșmanın amacı, projelerin ilk așamasında araștırmacılar için $E_{m}$ parametresinin belirlenmesine yönelik pratik bir eșitlik önermek ve doğrulamasını istatistik yöntemlerle yapmaktır.

\section{JEOLOJi, LABORATUVAR ve ARAZi ÇALIȘMALARI}

Çalışma sahası, Trabzon ili Çaykara ilçesi merkezinin güneyinde yer almaktadır. İnceleme alanı jeolojik olarak Doğu Pontid Tektonik Ünitesi'nin (Ketin, 1966) kuzey doğusunda yer almakta ve sahada Mesozoyik ve Senozoyik dönemine ait toleyitik ve kalk-alkalen kayaçlar gözlenmektedir. Mesozoyik dönemi, Liyas yașIı volkanitler ile bașlar ve Üst Jura-Alt Kretase yașlı karbonatlar ile devam eder. Üst Kretase döneminde yoğun bir volkanik aktivite görülür. Liyas 'ta bașlayıp Üst Kretase sonlarına kadar devam eden volkanik faaliyetler denizaltı volkanizması șeklinde olup çökel ara katkılarla birlikte istiflenme gösterirler. Paleosen sonlarında orojenezle birlikte granodiyorit yerleșimi gelișmiștir. Senozoyik döneminde ise eski alüvyon, yeni alüvyon ve yamaç molozları oluşmuştur. Tünel güzergâhı boyunca yeșilimsi gri renkli bazalt, az ayrıșmıș bazalt, orta derecede ayrıșmıș dasitik tüf, dasit, siyah renkli, az ayrışmış kireçtaşı, siyah renkli, sert, az ayrışmış bazalt, çok ayrışmış dasit-riyodasit yeșilimsi mor-gri renkli, orta derecede ayrıșmıș dasit-riyodasit ve epidotlu metabazalt gözlenmiştir.

Bu çalıșmada, çalıșılan tünel güzergâhının 37 farklı farklı örnekleme noktasından (Șekil 1) kaya blokları (24 volkanik, 8 metamorfik ve 5 tortul kayaç) laboratuvara getirilmiștir. ISRM (2007) tarafından önerildiği gibi karot örneklerinin alınabilmesi için, arazide her blok örneğinin makroskopik incelemeleri yapılarak çatlak, kırık ve ayrıșma içeren örnekler alınmamıștır. Laboratuvarda karot alma ve düzeltme makineleri deney örneklerinin hazırlanması için kullanılmıștır.
Laboratuvarda yapılan indeks deneyler ISRM (2007) tarafından önerilen yöntemlere göre yapılmıștır.

Kaya malzemelerine ait tek eksenli basınç ve deformabilite değerleri aynı deney ile elde edilmiștir. Deformabilite (elastisite modülü) değerlerini elde etmek için UCS deneyinde kullanılan karot örneklerinin eksen ve çapına paralel strain gage'ler yapıștırılarak deney esnasında kayaçta olușacak deformasyonlar hassas bir șekilde ölçülmüștür. Tek eksenli deformabilite deneyinde Kyowa deney aleti ile kaya malzemelerinin elastisite modülleri $\left(E_{i}\right)$ belirlenmiștir. Deneylerde boy/çap (L/D) oranı 2.5 olan NX (54.7 mm) çaplı karot örnekleri kullanıımıștır. Her bir örnekleme noktası için 5 toplam 185 adet karot örnekleri kullanılmıștır. Deneyler, 300 ton kapasiteli bilgisayar kontrollü makine ile yükleme hızı 0.75 $\mathrm{MPa} / \mathrm{s}$ arasında olacak șekilde uygulanmıștır.

Nokta yükleme deneylerinde (eksenel yöntem) ise L/D oranı $0.5-0.55$ arasında olan karot örnekleri kullanılmıștır. Deneylerde, dijital nokta yükleme deney aleti kullanılmıș olup, belirlenen nokta yükü dayanım değerleri $\left(I_{s}\right)$ değerleri referans çapa $(D=50 \mathrm{~mm})$ göre düzeltilerek $\mathrm{I}_{\mathrm{s}(50)}$ elde edilmiștir.

Örneklemenin yapıldığı noktalarda süreksizliklerin mühendislik özelliklerine yönelik çalışmalar ISRM (1981) tarafından önerilen yöntemlere göre yapılmıştır. Süreksizliklerin duruşu Brunton marka jeolog pusulasıyla, süreksizlik yüzeylerinin pürüzlülüğü Barton pürüzlülük tarağıyla, süreksizlik ara uzaklığı ve açıklığı şerit metre ve dijital kumpas ile belirlenmiştir. Geniș bir alanda kaya kütlesinin incelenmesine ve süreksizliklerden doğrudan ölçüm alınmasına olanak kılan bir yöntem olan hat etüdü yöntemi çalıșılan kazı aynalarında kullanılmıștır. Ulusay ve Sönmez (2007) tarafından önerildiği gibi hat etütlerinde yapay kırıklar dikkatli bir șekilde ayırtlanmıș ve değerlendirilmeye alınmamıștır. Patlatma veya mekanik kazı sonucu gelișmiș kırıklar, genellikle küçük (devamlılıkları az), pürüzlü, düzensiz, temiz ve gelișigüzel bir yönelime sahip olma gibi özellikleri ile doğal süreksizliklerden farklı olmaktadırlar. Arazi ve laboratuvar çalıșmalarına ait bazı görüntüler Șekil 2'de verilmiștir. 


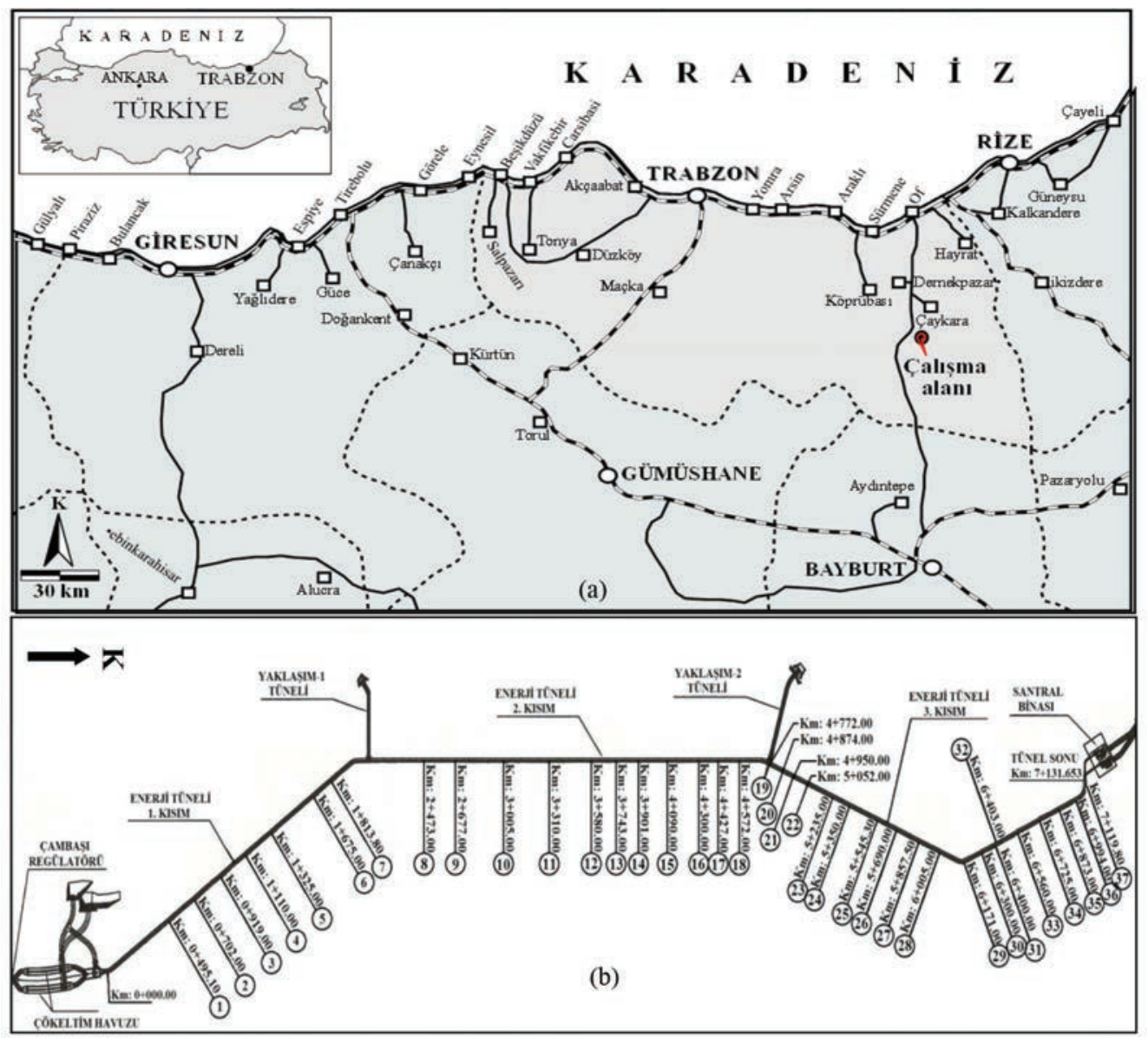

Șekil 1. Çalıșma alanı yer bulduru haritası (a) ve tünel güzergâhındaki örnekleme lokasyonları (b)

Figure 1. Location map of the study area (a) and sampling locations of tunnel route (b)

Kaya kalite göstergesi (RQD), ilk olarak Deere (1964) tarafından sondajdan alınan karot boylarından yararlanılarak temel kayalarının kalitesini ifade etmek için tanımlanmıștır. RQD, karotlu sondajlarla saptanabileceği gibi, kaya yüzleklerinden, yarma, șaft, galeri ve tünel duvarlarından yararlanılarak da saptanabilmektedir. Bu çalıșmada jeoteknik birimler için her bir tünel aynasında birbirine dik yönde iki farklı RQD değerleri hesaplanarak ortalaması alınmıștır. İnceleme alanında sistematik süreksizliklerin yanı sıra düzensiz süreksizliklerin de zaman zaman gözlenmiș olması nedeniyle RQD'yi belirlemek için Priest ve Hudson (1976) tarafından önerilen Eșitlik 1'den yararlanılmıștır.

$\mathrm{RQD}=100 \mathrm{e}^{(-0.1 \lambda)}(0.1 \lambda+1)$

Burada; $\lambda$ : 1 metre uzunluğundaki ölçüm hattını kesen ortalama süreksizlik sayısıdır.
$\mathrm{Bu}$ çalıșmada RMR'nin güncel versiyonu $\left(\mathrm{RMR}_{89}\right)$ kullanılmıștır. RMR puanı, kaya malzemesinin tek eksenli basınç dayanımı, kaya kalite göstergesi (\% RQD), süreksizlik aralığı, süreksizlik ve yeraltı suyu durumuna bağlı olarak hesaplanmaktadır. Daha hassas puanlama yapmak amacıyla tek eksenli basınç dayanımı, $\% R Q D$ ve süreksizlik ara uzaklığı parametreleri için RMR sisteminin son versiyonunda belirtilen parametre-puan grafikleri kullanılmıștır. $Q$ sınıflama sistemi için RQD, eklem takım sayısı $\left(J_{n}\right)$, eklem pürüzlülük sayısı $\left(J_{\mathrm{r}}\right)$, eklem alterasyon sayısı $\left(J_{a}\right)$, eklem suyu azaltma faktörü $\left(J_{w}\right)$ ve gerilme azaltma faktörü (SRF) belirlenmiștir. RMR ve $Q$ puanlamasında kullanılan ayrıntılı parametre ve çizelgelere bu çalıșmada yer verilememiș olup, bu konuda literatürden yararlanılabilir (Bieniawski, 1989; Barton, 2002; Ulusay ve Sönmez, 2007). Deneylerde kullanılan kayaç 


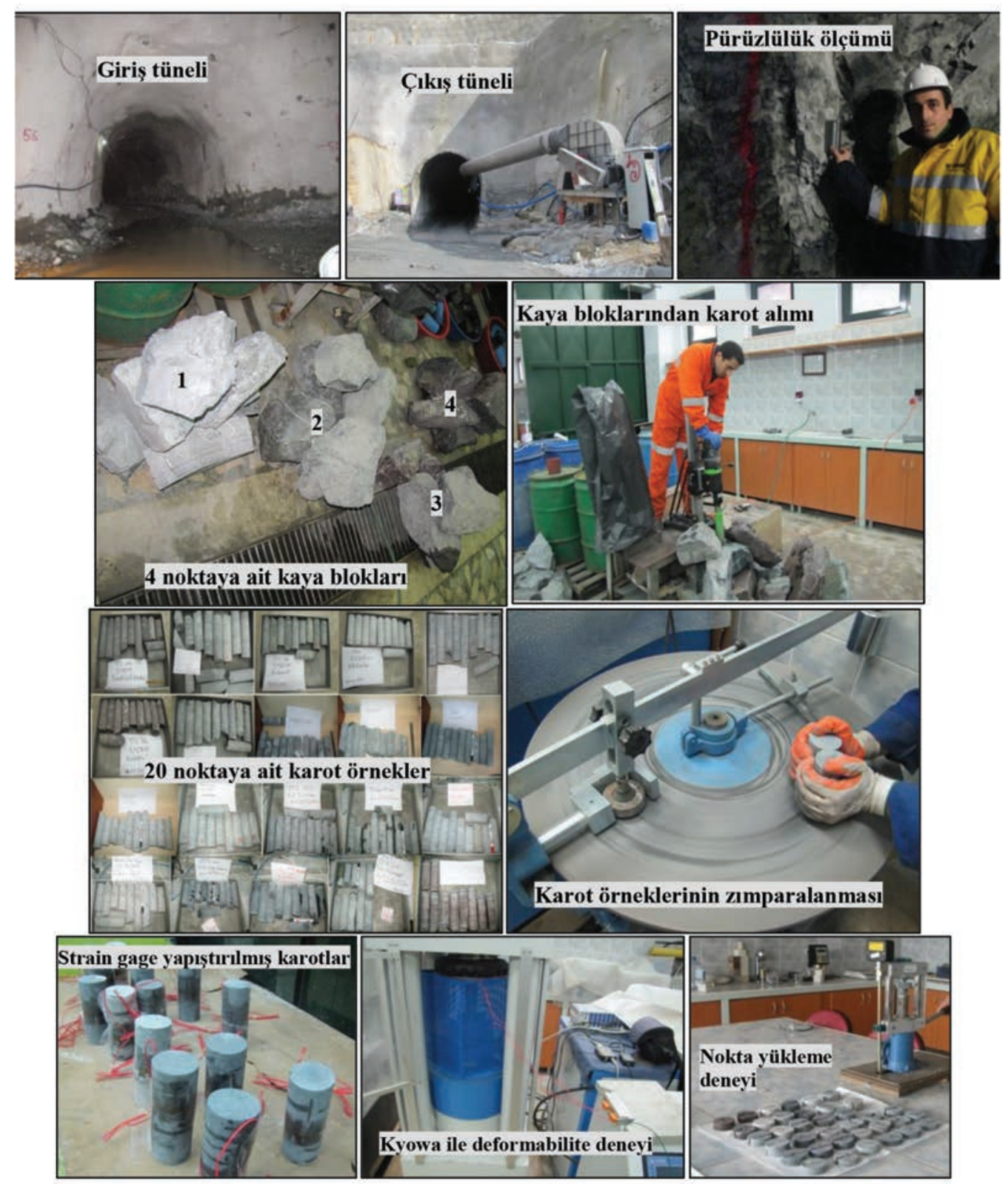

Șekil 2. Arazi ve laboratuvar çalıșmaları Figure 2. Field and laboratory studies

isimleri, örnek noktalarına karșilık gelen tünel doğrultusu ve ortalama değerler Çizelge 1'de yer almaktadır.

\section{BULGULAR ve TARTIȘMA}

\section{RMR ve Q Arasındaki İlișki}

RMR ve $Q$ sistemlerin arasındaki korelasyonu kullanarak birinden diğerini tahmin etmek mümkündür (Laderian ve Abaspoor, 2012). Bu amaca yönelik olarak literatürde çeșitli eșitlikler önerilmiștir (Bieniawski, 1976; Kaiser ve Gale, 1985; Abad vd., 1983; Barton, 1995; Tuğrul, 1998). Literatürde araștırmacıların büyük çoğunluğu RMR ve $Q$ arasında așağıdaki logaritmik denklem biçiminde eșitlikler önermișlerdir (Eșitlik 2).

$\mathrm{RMR}=\mathrm{A} \operatorname{Ln}(\mathrm{Q})+\mathrm{B}$

A ve B sırasıyla $5-15$ ve 35-60 arasında değișen katsayılardır (Zhang, 2004). Araștırmacılar 
Çizelge 1. Örnek yerleri ve deney sonuçları

Table 1. Test locations and related properties of rock material/masses

\begin{tabular}{|c|c|c|c|c|c|c|c|c|}
\hline $\begin{array}{l}\text { Örnek } \\
\text { Kodu }\end{array}$ & Tünel km'si & Doğrultu & Litoloji & $\mathrm{E}_{\mathrm{i}}(\mathrm{GPa})$ & $\%$ RQD & Is $\mathbf{s}_{(50)}$ & $\mathbf{R M R}_{89}$ & $\mathbf{Q}$ \\
\hline 1 & $0+495.10$ & K35B & Bazalt & $86.25 \pm 8.7$ & $83 \pm 2.1$ & $9.95 \pm 2.4$ & 74.7 & 14.76 \\
\hline 2 & $0+702.00$ & K35B & Metabazalt & $73.5 \pm 4.1$ & $83 \pm 2.1$ & $8.61 \pm 1.6$ & 73.5 & 14.76 \\
\hline 3 & $0+919.00$ & K35B & Metabazalt & $72.5 \pm 3.8$ & $83 \pm 2.1$ & $3.79 \pm 0.7$ & 55.5 & 14.76 \\
\hline 4 & $1+110.00$ & K35B & Metabazalt & $58.5 \pm 1.9$ & $84 \pm 0.0$ & $7.8 \pm 1.7$ & 72.9 & 14.93 \\
\hline 5 & $1+325.00$ & K35B & Metabazalt & $35.0 \pm 2.7$ & $83 \pm 2.1$ & $7.1 \pm 1.2$ & 72.3 & 14.76 \\
\hline 6 & $1+675.00$ & K35B & Bazalt & $71.5 \pm 2.4$ & $76 \pm 2.1$ & $5.32 \pm 0.9$ & 64.5 & 7.6 \\
\hline 7 & $1+813.80$ & K35B & Bazalt & $74.8 \pm 3.4$ & $76 \pm 2.1$ & $6.47 \pm 1.1$ & 55.9 & 7.6 \\
\hline 8 & $2+473.00$ & $K-G$ & Bazalt & $93.7 \pm 4.6$ & $84 \pm 0.0$ & $8.09 \pm 1.4$ & 68.4 & 14.93 \\
\hline 9 & $2+677.00$ & $K-G$ & Metabazalt & $66.5 \pm 3.9$ & $79 \pm 2.8$ & $6.14 \pm 0.3$ & 69.2 & 14.04 \\
\hline 10 & $3+005.00$ & $K-G$ & Metabazalt & $59.0 \pm 4.6$ & $83 \pm 2.1$ & $8.76 \pm 1.6$ & 70.8 & 14.76 \\
\hline 11 & $3+310.00$ & $K-G$ & Metabazalt & $31.5 \pm 1.4$ & $76 \pm 2.1$ & $4.9 \pm 0.6$ & 60.4 & 7.6 \\
\hline 12 & $3+580.00$ & $K-G$ & Metabazalt & $26.0 \pm 4.7$ & $79 \pm 2.8$ & $4.97 \pm 1.0$ & 67 & 10.53 \\
\hline 13 & $3+743.00$ & $K-G$ & Bazalt & $15.5 \pm 2.5$ & $79 \pm 2.8$ & $5.35 \pm 1.2$ & 55.5 & 10.53 \\
\hline 14 & $3+901.00$ & $K-G$ & Bazalt & $11.5 \pm 0.4$ & $79 \pm 2.8$ & $2.76 \pm 0.2$ & 48 & 10.53 \\
\hline 15 & $4+090.00$ & $K-G$ & Dasit & $20.0 \pm 4.6$ & $76 \pm 2.1$ & $3.77 \pm 0.7$ & 49.9 & 7.6 \\
\hline 16 & $4+300.00$ & $K-G$ & Bazalt & $51.0 \pm 6.5$ & $76 \pm 2.1$ & $4.14 \pm 1.8$ & 52 & 7.6 \\
\hline 17 & $4+427.00$ & $K-G$ & Dasit & $20.0 \pm 1.5$ & $70 \pm 5.7$ & $3.42 \pm 0.9$ & 50.8 & 3.5 \\
\hline 18 & $4+572.00$ & $K-G$ & Dasit & $20.0 \pm 1.4$ & $83 \pm 2.1$ & $3.87 \pm 0.1$ & 67.6 & 14.76 \\
\hline 19 & $4+772.00$ & $\mathrm{~K} 23 \mathrm{D}$ & Dasit & $45.2 \pm 3.2$ & $79 \pm 2.8$ & $3.61 \pm 0.7$ & 54.8 & 4.68 \\
\hline 20 & $4+874.00$ & K23D & Dasit & $19.5 \pm 2.4$ & $76 \pm 2.1$ & $3.44 \pm 0.3$ & 64.1 & 7.6 \\
\hline 21 & $4+950.00$ & K23D & Kireçtașı & $78.5 \pm 6.8$ & $81 \pm 0.0$ & $5.56 \pm 0.5$ & 65.9 & 10.8 \\
\hline 22 & $5+052.00$ & K23D & Kireçtașı & $32.5 \pm 1.6$ & $67 \pm 4.9$ & $5.2 \pm 0.7$ & 43.2 & 2.23 \\
\hline 23 & $5+235.00$ & K23D & Bazalt & $71.5 \pm 7$ & $83 \pm 2.1$ & $6.67 \pm 1.2$ & 69.8 & 14.76 \\
\hline 24 & $5+350.00$ & K23D & Kireçtașı & $54.5 \pm 8.7$ & $79 \pm 2.8$ & $5.6 \pm 0.2$ & 56.7 & 10.53 \\
\hline 25 & $5+545.30$ & $\mathrm{~K} 23 \mathrm{D}$ & Kireçtașı & $62.5 \pm 4.6$ & $76 \pm 2.1$ & $5.19 \pm 0.3$ & 61.7 & 10.13 \\
\hline 26 & $5+690.00$ & K23D & Bazalt & $17 \pm 3.4$ & $83 \pm 2.1$ & $4.91 \pm 0.8$ & 53.1 & 11.06 \\
\hline 27 & $5+857.50$ & K23D & Volkanik breș & $15.5 \pm 3.5$ & $70 \pm 5.7$ & $2.13 \pm 0.3$ & 57.1 & 7 \\
\hline 28 & $6+005.00$ & K23D & Kireçtașı & $26.5 \pm 3.2$ & $79 \pm 2.8$ & $5.69 \pm 0.4$ & 65.8 & 10.53 \\
\hline 29 & $6+171.00$ & K6B & Bazalt+dasit & $41 \pm 4.9$ & $76 \pm 2.1$ & $6.11 \pm 0.4$ & 56 & 10.13 \\
\hline 30 & $6+300.00$ & $\mathrm{~K} 25 \mathrm{~B}$ & Bazalt & $74 \pm 4.7$ & $76 \pm 2.1$ & $6.58 \pm 1.2$ & 50.2 & 7.6 \\
\hline 31 & $6+400.00$ & $\mathrm{~K} 25 \mathrm{~B}$ & Dasit & $18.5 \pm 3.4$ & $79 \pm 2.8$ & $3.31 \pm 1.1$ & 51.1 & 10.53 \\
\hline 32 & $6+403.00$ & $\mathrm{~K} 25 \mathrm{~B}$ & Dasit & $17 \pm 2.1$ & $83 \pm 2.1$ & $3.3 \pm 0.5$ & 51.5 & 11.07 \\
\hline 33 & $6+560.00$ & K25B & Bazalt & $58.5 \pm 6.4$ & $83 \pm 2.1$ & $6.42 \pm 1.8$ & 69.5 & 11.07 \\
\hline 34 & $6+725.00$ & K25B & Dasit & $36.5 \pm 4.2$ & $76 \pm 2.1$ & $6.76 \pm 0.2$ & 59.5 & 7.6 \\
\hline 35 & $6+873.00$ & K25B & Dasit & $21 \pm 1.4$ & $76 \pm 2.1$ & $4.24 \pm 0.4$ & 51.7 & 7.6 \\
\hline 36 & $6+994.00$ & $\mathrm{~K} 25 \mathrm{~B}$ & Dasit & $63.5 \pm 3.4$ & $79 \pm 2.8$ & $5.02 \pm 1.4$ & 69.2 & 10.53 \\
\hline 37 & $7+119.80$ & D-B & Dasit & $37.1 \pm 3.2$ & $70 \pm 5.7$ & $4.27 \pm 1.1$ & 58.9 & 1.75 \\
\hline
\end{tabular}


tarafından $Q$ sisteminden RMR puanını belirlemeye yönelik önerilen ve bu çalıșma kapsamında kullanılan ampirik eşitlikler Çizelge 2'de verilmiştir. Bu çalıșma kapsamında $R M R$ ve $Q$ arasında orta derecede $(r=0.57)$ pozitif logaritmik bir ilișki gözlenmiștir (Șekil 3a). RMR ve $Q$ sistemi arasında pozitif bir ilișki gözlenmesinin nedeni her iki sistemin benzer kaya kütle özelliklerini girdi parametresi olarak kullanmasından kaynaklanmaktadır (Laderian ve Abaspoor, 2012). Ulusay ve Sönmez (2007) ise kaya malzemesinin dayanımı ve gerilme için yapılan değerlendirmenin her iki sistemde oldukça farkIı olduğunu belirtmișlerdir. RMR ve $Q$ arasında çok yüksek bir ilișki elde edilememesinin nedeni iki sistem arasındaki girdi parametrelerinin değerlendirmesindeki farklııktan kaynaklanabileceği düșünülmüștür. Bu çalıșmadan elde edilen ampirik eşitlik ile karşılaştırmada kullanılan eşitliklere (Çizelge 2) bakıldığında, Eșitlik 2'de belirtilen $A$ ve $B$ katsayıları ile örtüștüğü anlașılmaktadır. Çizelge 2'deki eșitlikler ile bu çaIıșmada elde edilen eșitlik $Q$ sisteminden RMR tahmini açısından karșılaștırılmıștır (Șekil 3b). Barton (1995) ve Tuğrul (1998) tarafından önerilen eșitlikler sırasıyla en yüksek ve en düșük RMR değerlerini vermiștir. Bieniawski (1976), Abad vd. (1983) ve Kumar vd. (2004) tarafından önerilen eșitlikler ile bu çalıșmada geliștirilen eșitliğin nispeten yakın RMR değerleri verdiği görülmüștür (Șekil 3b).

\section{Kaya Kütleleri Deformasyon Modülünün Belirlenmesi}

Kaya kütlelerinin deformasyon modülü $\left(E_{m}\right)$, mühendislik jeolojisi uygulamalarının tasarımında (sayısal analiz vb.) kullanılan en önemli parametrelerden biridir. Clerici (1993) deformasyon modülünün ampirik eșitlikler ile tahmin edilmesi için iki seçenek sunmuștur; a) "eșitlikte kullanılan parametreler düșük maliyetle ve kolay ulașılabilir olmalı", b) "eșitliklere literatürde yaygın olarak yer verilmeli" (Kayabașı vd., 2003). Bu çalıșmada kullanılan eșitlikler bu kurala uymaktadır. Araștırmacılar tarafından $\mathrm{E}_{\mathrm{m}}$ parametresini pratik yoldan belirlemeye yönelik önerilen ampirik eşitlikler Çizelge 3'te, bu eșitliklerden bir kısmı kullanılarak hesap edilen her bir örnekleme noktasına ait deformasyon modülü değerleri ise
Çizelge 4'te verilmiștir. Literatürde deformasyon modülünün belirlenmesine yönelik araștırmacılar oldukça çok sayıda ampirik eşitlik önermişlerdir. Ancak karşılaştırma grafiklerinin daha iyi anlaşılabilmesi için daha az eşitliğe yer verilebilmiştir.

Literatürde $E_{m}$ parametresini tahmin etmek için üretilen eșitliklerin çoğu kaya kütle sınıflama sistemlerinden (RMR, Q, RMi vb.) olușmaktadır. Farklı olarak $\mathrm{E}_{\mathrm{m}}$ parametresini tahmin etmek için; Kayabașı vd. (2003) ayrıșma derecesi, RQD ve kaya malzemesine ait elastisite modülü parametrelerini içeren bir eșitlik önermiștir. Gökçeoğlu vd. (2003) ise bu parametrelere ilave olarak tek eksenli basınç dayanım (UCS) değerini de eșitliğe ilave etmiștir. Zhang ve Einstein (2004) ise sadece RQD ve $E_{i}$ parametrelerini içeren bir eșitlik geliștirmiștir. Eșitliklere bakıldığında süreksizlik parametreleri ile birlikte kaya malzemesinin dayanım özellikleri ve/veya deformasyon özellikleri $\mathrm{E}_{\mathrm{m}}$ parametresinin tahmininde kullanılmıștır.

Khabbazi vd. (2013) Süreksizlik özellikleri ve kaya dayanımı kaya kütlelerinin deformasyonuna en çok etki eden iki unsur olduklarını belirtmișlerdir. Bu çalıșmada üretilen eșitlik hem süreksizlik özellikleri (RQD) hem de kaya dayanımını $\left(\right.$ Is $\left._{(50)}\right)$ içermektedir. Kayaçların UCS ile $E_{i}$ parametreleri arasında pozitif bir ilișki olduğu bilinmektedir (Ocak, 2008). Ayrıca, Is ${ }_{(50)}$ ile UCS arasında benzer bir ilișki mevcut olup literatürde bu konuda oldukça çok çalıșma bulunmaktadır (Singh vd., 2012; Karaman ve Kesimal, 2013; Karaman vd., 2014). Dolayısıyla $I_{(50)}$ ile $E_{i}$ arasında da benzer bir ilișki olduğu düșünülmüștür. Ayrıca, nokta yükü indisi değișim aralığı ile çalıșma sahasında yapılan gözlem ve analizler neticesinde elde edilen RQD aralık değerleri birlikte değerlendirilmiștir. Bu noktadan hareketle, diğer deneylere (UCS ve $E_{i}$ ) göre elde edilmesi çok daha kolay ve ucuz olan Is ${ }_{(50)}$ parametresinin RQD ile birlikte $E_{m}$ tahmininde kullanımı üzerinde bir eșitlik üretilmiștir (Eșitlik 3). Olușan grafik eğrisi, literatürdeki bazı önemli eșitliklerle kıyaslanarak araștırmacıları (literatürdeki eșitliklerden türetilen $\mathrm{E}_{\mathrm{m}}$ ortalamalarına göre) kısmen güvenli tarafta bırakacak șekilde optimize edilmiștir. Çoklu istatistiksel karșılaștırma (One way ANOVA) ile de eğrinin kullanılabilirliği teyit edilmiștir. 
Çizelge 2.RMR ve $Q$ arasındaki ilișki

Table 2. The relationship between $R M R$ and $Q$

\begin{tabular}{cc}
\hline Araștırmacı & Eșitlik \\
\hline Bieniawski (1976) & $\mathrm{RMR}=9 \mathrm{LnQ}+44$ \\
Abad vd. (1983) & $\mathrm{RMR}=10.5 \mathrm{LnQ}+41.8$ \\
Barton (1995) & $\mathrm{RMR}=15 \mathrm{LnQ}+50$ \\
Tuğrul (1998) & $\mathrm{RMR}=7 \mathrm{LnQ}+36$ \\
Kumar vd. (2004) & $\mathrm{RMR}=6.4 \mathrm{LnQ}+49.6$ \\
\hline
\end{tabular}
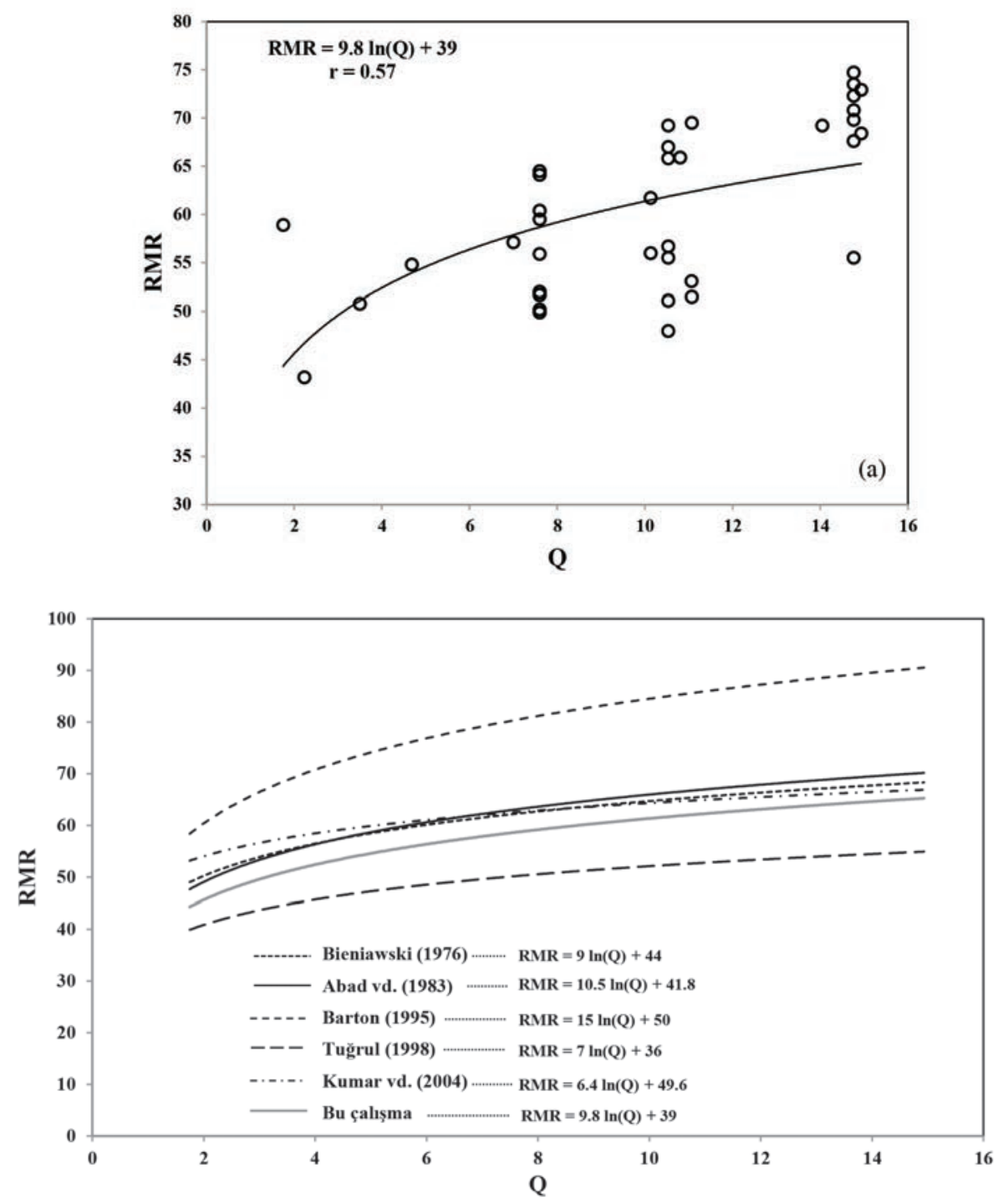

Șekil 3. RMR ve $Q$ arasındaki ilișki (a) ve RMR tahmininde önceki çalıșmalarla önerilen eșitliğin karșılaștırılması (b) Figure 3. The relationship between $R M R$ and $Q$ (a) and the comparison of proposed equation with previous studies for the estimation of RMR (b) 
Çizelge 3.Deformasyon modülü tahmininde kullanılan bazı ampirik eșitlikler

Table 3. Some empirical equations used for estimation of deformation modulus

\begin{tabular}{|c|c|c|}
\hline Araștırmacı & Eșitlik & Not \\
\hline *Bieniawski (1978) & $E_{m}=2 R M R-100(G P a)$ & $\mathrm{RMR}>50$ \\
\hline *Serafim ve Pereira (1983) & $\mathrm{E}_{\mathrm{m}}=10^{(\mathrm{RMR}-10) / 40}(\mathrm{GPa})$ & $\mathrm{RMR} \leq 50$ \\
\hline *Aydan vd. (1997) & \multicolumn{2}{|l|}{$\mathrm{E}_{\mathrm{m}}=0.0097 \mathrm{RMR}^{3.54}(\mathrm{MPa})$} \\
\hline${ }^{\star}$ Read vd. (1999) & \multicolumn{2}{|l|}{$\mathrm{E}_{\mathrm{m}}=0.1(\mathrm{RMR} / 10)^{3}(\mathrm{GPa})$} \\
\hline *Barton (2002) & \multicolumn{2}{|l|}{$E_{m}=10 Q_{c}^{1 / 3}, Q_{c}=Q U C S / 100$} \\
\hline Kayabaşı vd. (2003) & \multicolumn{2}{|c|}{$\mathrm{E}_{\mathrm{m}}=0.135\left[\frac{E_{i}\left(1+\frac{R Q D}{100}\right)}{W D}\right]^{1.1811} \quad(\mathrm{GPa})$} \\
\hline Gökçeoğlu vd. (2003) & \multicolumn{2}{|c|}{$\mathrm{E}_{\mathrm{m}}=0.001\left[\frac{\left(E_{i / \sigma_{c i}}\right)\left(1+\frac{\kappa Q D}{100}\right)}{W D}\right] \quad$ (GPa) } \\
\hline `Zhang ve Einstein (2004) & \multicolumn{2}{|l|}{$\mathrm{E}_{\mathrm{m}}=\left(10^{0.0186 R Q D-1.91}\right) \mathrm{E}_{\mathrm{i}}(\mathrm{GPa})$} \\
\hline Ramamurthy (2004) & \multicolumn{2}{|c|}{$\mathrm{E}_{\mathrm{m}}=E_{i} e^{-0.0035\lfloor 5(100-R M R)\rfloor}(\mathrm{GPa})$} \\
\hline Ramamurthy (2004) & \multicolumn{2}{|c|}{$\mathrm{E}_{\mathrm{m}}=E_{i} e^{-0.0035\lfloor 250(1-0.3 \log Q)\rfloor}(\mathrm{GPa})$} \\
\hline Sönmez vd. (2006) & \multicolumn{2}{|c|}{$\left.\mathrm{E}_{\mathrm{m}}=E_{i} 10[((R M R-100)(100-R M R) / 4000) \exp (-R M R / 100))\right]$} \\
\hline Chun vd. (2006) & \multicolumn{2}{|l|}{$\mathrm{E}_{\mathrm{m}}=0.3228 \mathrm{e}^{(0.0485 \mathrm{RMR})}(\mathrm{GPa})$} \\
\hline Ișık vd. (2008) & \multicolumn{2}{|l|}{$\mathrm{E}_{\mathrm{m}}=6.7 \mathrm{RMR}-103.06(\mathrm{MPa})$} \\
\hline Khabbazi vd. (2013) & \multicolumn{2}{|l|}{$E_{m}=9 E-7 R^{2} R^{3.868}$} \\
\hline
\end{tabular}

*: Bu çalıșmada kullanılan eșitlikler, $\sigma_{c i}$ : Kaya malzemesine ait tek eksenli basınç dayanımı

$E_{m}=I_{(50)} \times 10^{(0.01 * R Q D-0.25)}$

$\mathrm{Bu}$ eșitlik ile $\mathrm{E}_{\mathrm{m}}$ değerleri çalıșma sahasındaki kaya kütleleri için en düșük 6.0 en yüksek 37.8 GPa olarak bulunmuștur (Çizelge 4). RQD ve Is $_{(50)}$ 'nin en düșük ve en yüksek değerleri dikkate alınarak geliștirilen eșitlik ile bulunan $E_{m}$, literatürle uyumlu çıkmaktadır $(\approx 0.05-90 \mathrm{GPa})$. En yüksek değer ( $\approx 90 \mathrm{GPa}) \mathrm{RQD}$ 'nin $\% 100$ ve Is ${ }_{(50)}$ değerinin ise $>15 \mathrm{MPa}$ olduğu durum için geçerlidir. Literatürdeki RQD ve $\mathrm{Is}_{(50)}$ değerlerine bakıldığında, üretilen eșitlik ile genellikle 50 GPa'dan daha düșük değerler elde edilmektedir. RQD'nin 0 olduğu durumda kaya kütlelerinin $E_{m}$ içerebildiği bilinmektedir. Üretilen eşitlik ile RQD 0 olduğunda Is ${ }_{(50)}$ değerine bağlı olarak kaya kütlelerine yönelik $\mathrm{E}_{\mathrm{m}}$ değeri 0 olmamakta ve çok düșük bir değer elde edilmektedir. Benzer durum Zhang ve Einstein (2004) eșitliği için de söz konusudur. Literatürde UCS değerleri genellikle 0-200 MPa arasında $\mathrm{E}_{\mathrm{i}}$ değerleri ise 0-90 GPa arasında değișmektedir. Kayaçların nokta yükü dayanım indeksi değerleri $\left(\mathbf{I s}_{(50)}\right)$ ise genellikle $10 \mathrm{MPa}$ 'dan daha düșük, nadiren de bu değerin üzerinde olduğu literatürden anlașılmaktadır (Kahraman, 2001). Is ${ }_{(50)}$ değerlerinin genellikle 0-15 MPa gibi dar bir aralıkta değișmesi ve șekilsiz örnekler üzerinde de deneyin yapılabilmesi eșitlik geliștirme açısından bir avantaj olarak düșünülmüștür. Ayrıca $I_{(50)}$ parametresi sık eklemli ve yüksek kaliteli karot alımının zorlaștığı piroklastik kaya ortamlarda da belirlenebilmektedir.

Ampirik ilișkiler projelerin ilk așamalarında ve özellikle verilerin sınırlı olduğu güzergâh belirleme çalıșmalarında uygulanmaktadır (Khabbazi vd., 2013). Ancak, UCS ve $E_{i}$ gibi yüksek kaliteli 
Çizelge 4. Ampirik eșitlikler yardımıyla hesaplanan $\mathrm{E}_{m}$ değerleri

Table 4. Calculated values of $E_{m}$ by means of empirical equations

\begin{tabular}{|c|c|c|c|c|c|c|c|}
\hline $\begin{array}{l}\text { Örnek } \\
\text { kodu }\end{array}$ & Bu çalıșma & $\begin{array}{c}\text { Bieniawski } \\
\text { (1978) }\end{array}$ & $\begin{array}{c}\text { Serafim ve } \\
\text { Pereira (1983) }\end{array}$ & $\begin{array}{l}\text { Aydan vd. } \\
\text { (1997) }\end{array}$ & $\begin{array}{l}\text { Read vd. } \\
\text { (1999) }\end{array}$ & $\begin{array}{l}\text { Barton } \\
(2002)\end{array}$ & $\begin{array}{l}\text { Zhang ve Einstein } \\
(2004)\end{array}$ \\
\hline 1 & 37.8 & 49.4 & - & 41.5 & 41.7 & 30.8 & 37.1 \\
\hline 2 & 32.7 & 47 & - & 39.2 & 39.7 & 28.6 & 31.6 \\
\hline 3 & 14.4 & 11 & - & 14.5 & 17.1 & 21.4 & 31.2 \\
\hline 4 & 30.3 & 45.8 & - & 38.1 & 38.7 & 27.9 & 26.3 \\
\hline 5 & 27.0 & 44.6 & - & 37.0 & 37.8 & 27.0 & 15.1 \\
\hline 6 & 17.2 & 29 & - & 24.7 & 26.8 & 19.3 & 22.8 \\
\hline 7 & 20.9 & 11.8 & - & 14.9 & 17.5 & 20.6 & 23.9 \\
\hline 8 & 31.5 & 36.8 & - & 30.4 & 32.0 & 28.3 & 42.1 \\
\hline 9 & 21.3 & 38.4 & - & 31.7 & 33.1 & 23.8 & 24.1 \\
\hline 10 & 33.3 & 41.6 & - & 34.3 & 35.5 & 25.4 & 25.4 \\
\hline 11 & 15.9 & 20.8 & - & 19.6 & 22.0 & 17.5 & 10.0 \\
\hline 12 & 17.2 & 34 & - & 28.3 & 30.1 & 20.4 & 9.4 \\
\hline 13 & 18.6 & 11 & - & 14.5 & 17.1 & 19.9 & 5.6 \\
\hline 14 & 9.6 & - & 8.9 & 8.7 & 11.1 & 15.3 & 4.2 \\
\hline 15 & 12.2 & - & 9.9 & 10.0 & 12.4 & 16.7 & 6.4 \\
\hline 16 & 13.4 & 4 & - & 11.5 & 14.1 & 18.8 & 16.3 \\
\hline 17 & 9.6 & 1.6 & - & 10.6 & 13.1 & 12.9 & 4.9 \\
\hline 18 & 14.7 & 35.2 & - & 29.2 & 30.9 & 22.0 & 8.6 \\
\hline 19 & 12.5 & 9.6 & - & 13.9 & 16.5 & 14.5 & 16.4 \\
\hline 20 & 11.1 & 28.2 & - & 24.2 & 26.3 & 16.2 & 6.2 \\
\hline 21 & 20.2 & 31.8 & - & 26.6 & 28.6 & 23.3 & 31.0 \\
\hline 22 & 13.7 & - & 6.8 & 6.0 & 8.1 & 12.7 & 7.0 \\
\hline 23 & 25.4 & 39.6 & - & 32.7 & 34.0 & 24.5 & 30.8 \\
\hline 24 & 19.4 & 13.4 & - & 15.6 & 18.2 & 21.2 & 19.8 \\
\hline 25 & 16.8 & 23.4 & - & 21.1 & 23.5 & 19.7 & 19.9 \\
\hline 26 & 18.7 & 6.2 & - & 12.4 & 15.0 & 20.4 & 7.3 \\
\hline 27 & 6.0 & 14.2 & - & 16.0 & 18.6 & 14.2 & 3.8 \\
\hline 28 & 19.7 & 31.6 & - & 26.5 & 28.5 & 23.3 & 9.6 \\
\hline 29 & 19.8 & 12 & - & 15.0 & 17.6 & 21.2 & 13.1 \\
\hline 30 & 21.3 & 0.4 & - & 10.2 & 12.7 & 21.2 & 23.6 \\
\hline 31 & 11.5 & 2.2 & - & 10.8 & 13.3 & 19.3 & 6.7 \\
\hline 32 & 12.5 & 3 & - & 11.1 & 13.7 & 19.4 & 7.3 \\
\hline 33 & 24.4 & 39 & - & 32.2 & 33.6 & 22.8 & 25.2 \\
\hline 34 & 21.9 & 19 & - & 18.6 & 21.1 & 21.6 & 11.6 \\
\hline 35 & 13.7 & 3.4 & - & 11.3 & 13.8 & 18.8 & 6.7 \\
\hline 36 & 17.4 & 38.4 & - & 31.7 & 33.1 & 22.6 & 23.0 \\
\hline 37 & 12.0 & 17.8 & - & 17.9 & 20.4 & 11.6 & 9.1 \\
\hline
\end{tabular}


karot gerektiren deneyler yeraltı projelerinin ilk așamalarında temsili örnek alınamadığından çoğunlukla yapılamamaktadır (Karaman ve Kesimal, 2013). Kaya (2012) Cankurtaran (Hopa-Artvin) tünel güzergâhını belirlemeye yönelik yaptığı doktora çalıșmasında, kaya malzemelerinin tek eksenli basınç dayanımını Is $_{(50)}$ ' den tahmin etmiștir. Karslı (2009) yaptığı yüksek lisans çalıșmasında Artvin bölgesindeki karayolu șevlerini duraylılık açısından incelediği çalışmasında tek eksenli basınç dayanımı parametresini Schmidt çekici deneyinden elde etmiștir.

\section{$E_{m}$ değerlerinin karșılaștırılması}

Çizelge 1'deki değerler kullanılarak 6 farklı araștırmacıya (Çizelge 3) göre çalıșma sahasındaki kaya kütlelerinin deformasyon modülü $\left(E_{m}\right)$ değerleri belirlenmiștir (Çizelge 4). Çizelge 4 incelendiğinde $\mathrm{E}_{m}$ değerleri; Bieniawski (1978) eșitliği için en düșük 0.4 en yüksek $49.4 \mathrm{GPa}$, Aydan vd. (1997) eșitliği için en düșük 6 en yüksek 41.5 GPa, Read vd. (1999) eşitliği için en düşük 8.1 en yüksek 41.7 GPa, Barton (2002) eșitliği için en düșük 11.6 en yüksek $30.8 \mathrm{GPa}$ ve Zhang ve Einstein (2004) eșitliği için en düșük 3.8 en yüksek 42.1 GPa olarak bulunmuștur. Bieniawski (1978) eșitliği RMR değerinin > 50 olduğu durumda geçerli iken, Serafim ve Pereira (1983) eșitliği ise RMR değerinin $\leq 50$ olduğu durumda geçerli olmaktadır. Bu çalıșmada kapsamında tünel güzergâhındaki 37 farklı noktadan üç jeoteknik birime ait RMR değerleri 50'nin altında olmuștur (Çizelge 1). Verilerde bir bütünlük sağlamak için Bieniawski (1978) ve Serafim ve Pereira (1983) eșitlikleri birlikte kullanılmıștır. Çalıșma sahasındaki jeoteknik birimlerin RMR değerleri ise 43.2-74.7 arasında değișmiștir (Karaman vd., 2013).

$E_{m}$ değerleri Șekil 4'te birlikte değerlendirilmiștir. Aynı örnekleme noktası için birbirinden oldukça farklı $E_{m}$ değerlerinin elde edildiği görülmektedir. RMR sisteminden elde edilen eșitliklerin genelde aynı eğilimde olduğu anlașılmıș ve Șekil 5'te gösterilmiștir. Șekil 5'ten de anlașılacağı gibi Bieniawski (1978) eșitliği diğerlerine nazaran kısmen farklı bir eğilim sunmaktadır. Aydan vd. (1997) ve Read vd. (1999) tarafından önerilen eșitlikler oldukça yakın $E_{m}$ değerleri vermiștir.
Șekil 6'te bu çalıșmadan üretilen eșitlik ile birbirine oldukça yakın $E_{m}$ değerleri sunan iki eșitliğin (Aydan vd., 1997; Read vd., 1999) karșılaștırılması yapılmıștır. Șekil 6'ya göre önerilen eşitlik ile kısmen daha düşük $E_{m}$ değerlerinin elde edildiği ve bu nedenle önerilen eșitliğin analizlerde araștırmacıları güvenli tarafta bırakabileceği düșünülmüștür.

Önerilen eşitlik yardımıyla bulunan $\mathrm{E}_{m}$ değerlerinin diğer eșitliklerden hesaplanan değerler ile benzerliği veya farkını test etmek için tek yönlü varyans analizi (Oneway ANOVA) yapılmıștır. Tek yönlü varyans analizi grup verilerinin normal dağılması koșulunu öne sürdüğünden önce normallik testleri (normality tests) ile verilerin normal dağılıma uygunluğu test edilmiștir. Kaya kütlelerinin $\mathrm{E}_{m}$ değerleri Kolmogorov-Simirnov'a göre normal dağılım göstermiştir (önem düzeyi (Asymp. Sig.) > 0.05). Ayrıca, verilerin normal dağılımlarını gösteren histogram grafikleri Șekil 7'de yer almaktadır. Șekil 7 incelendiğinde bu çalıșma ve Barton (2002) tarafından önerilen eșitliklere ait önem düzeyleri diğer eșitliklerden daha yüksek çıkmıștır. Tek yönlü varyans değerlerinin sonuçlarını incelemeden önce varyansların homojenliği test edilmiștir. Grupların homojen olması için anlamlıık seviyesi (Sig.) > 0.05 olması gerekmektedir. Eğer bu teste göre anlamlılık seviyesi $<0.05$ ise "Grup ortalamaları birbirinden önemli düzeyde farklıdır" veya "Grup ortalamalarından en az biri diğerlerinden farklıdır" yorumları yapılmaktadır (Özdamar, 2011). Bu teste göre verilerin homojen olmadığı (Levene testi $F=20.009$, anlamlılık seviye$\mathrm{si}=0.000$ ) anlașılmıștır. Bu nedenle Tamhane's T2 post-hoc testi grupların benzer olup olmadığını kontrol etmek için kullanılmıștır (Çizelge 5). Hochberg ve Tamhane (1987), Tamhane's T2 ve Tamhane's T3 testlerinin tutucu ve dikkatli karșılaștırmalar yaptığını belirtmektedirler. $\mathrm{Bu}$ analizde anlamlıık seviyesi 1.000'e yaklaștıkça grupların benzerliğinin arttığı bilinmektedir. Anlamlılık seviyesi 1.000 olduğunda ise grupların birebir aynı olduğu anlamı çıkmaktadır. Bu çalıșmada önerilen eșitlikle hesaplanan $E_{m}$ değerleri ile diğer eșitliklerden elde edilen $E_{m}$ değerleri arasında fark olmadığı (benzer oldukları) Tamhane's T2 testi ile anlașılmıștır (anlamlıık seviyesi > 0.05). Çizelge 5 incelendiğinde grup 


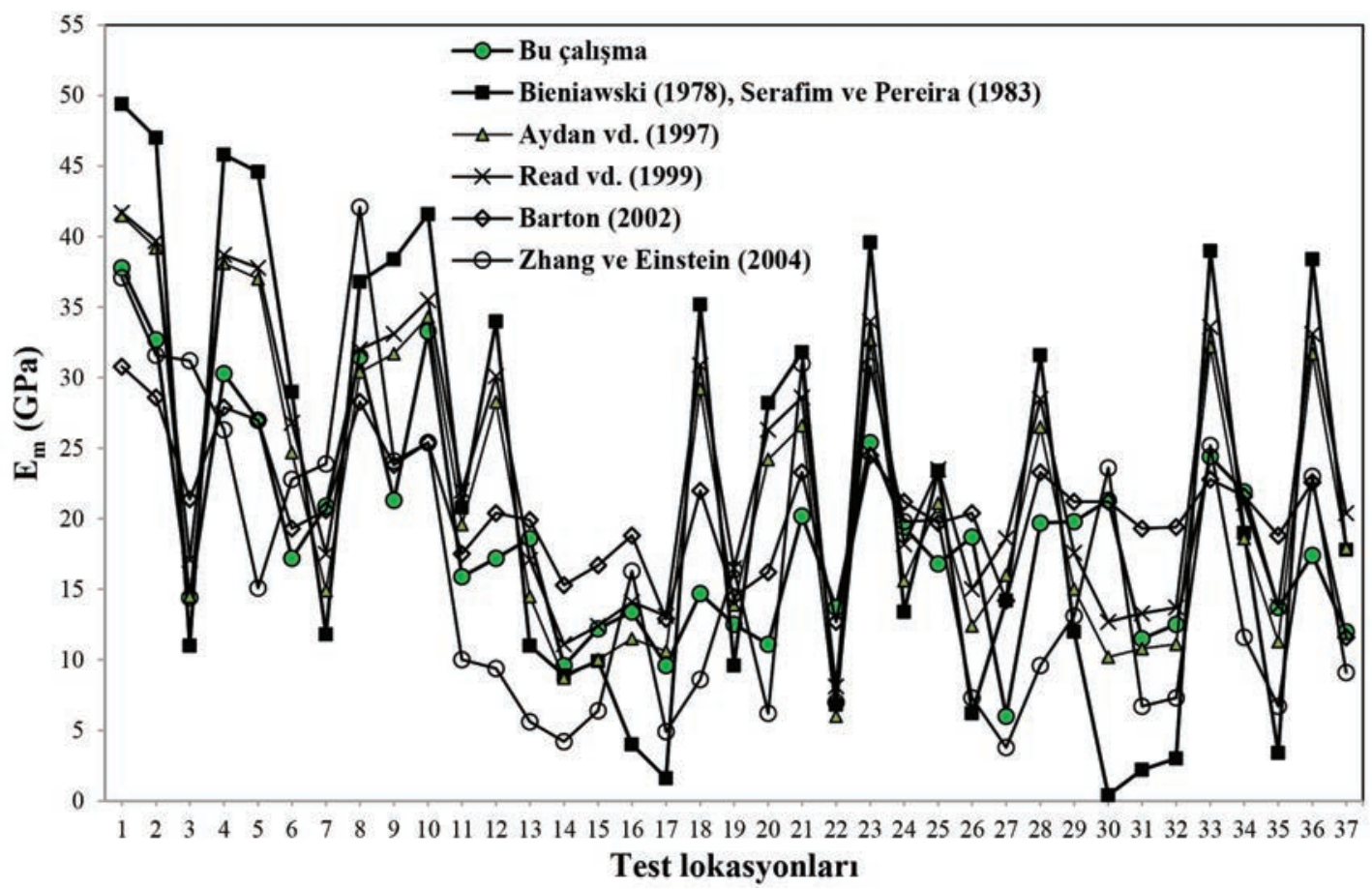

Șekil 4. $E_{m}$ değerlerinin örnek noktasına göre değișimi

Figure 4. Variations of $E_{m}$ values according to the test locations

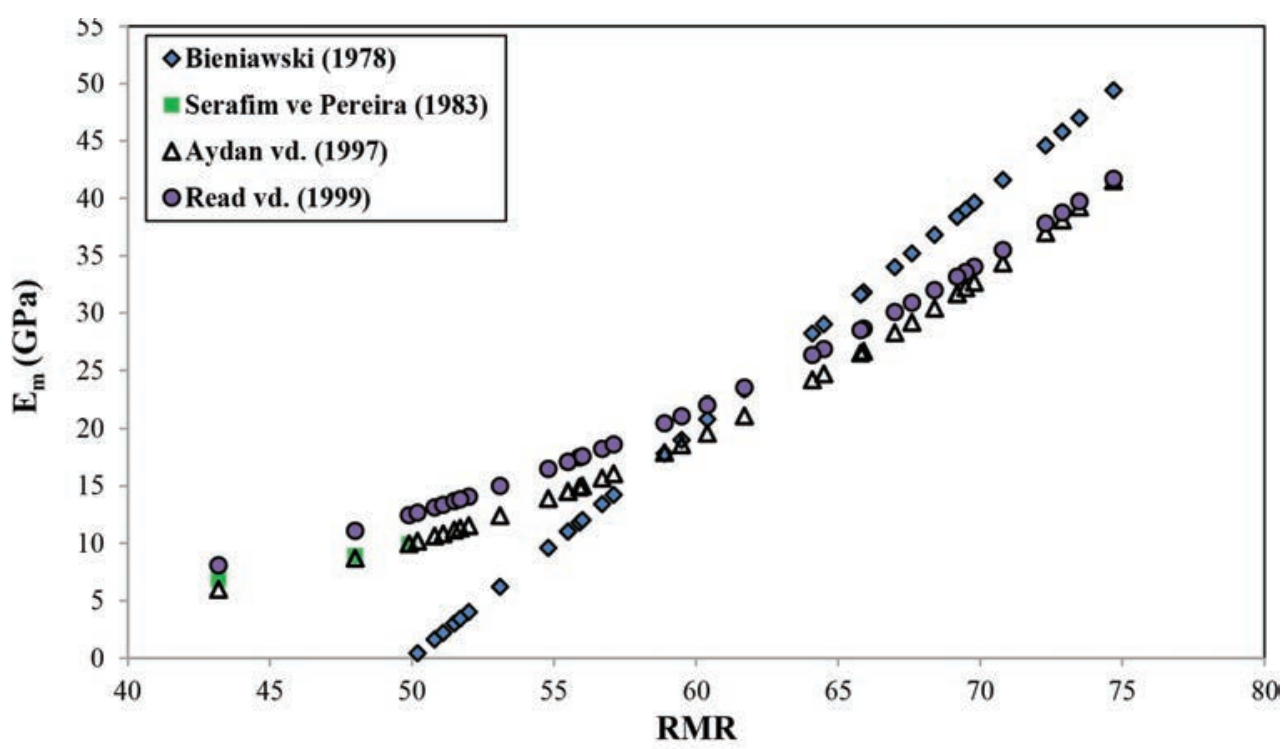

Șekil 5. RMR ile $\mathrm{E}_{\mathrm{m}}$ arasındaki ilișki

Figure 5. Relationship between $R M R$ and $E_{m}$

1 (bu çalıșma) ile grup 6'nın (Zhang ve Einstein, 2004) diğer gruplara göre daha çok benzerlik gösterdiği görülmektedir. Kayaçların dayanımı arttıkça $E_{i}$ ve $I_{(50)}$ değerleri artmaktadır. Ayrıca her iki eșitliğin (grup 1 ve grup 6) RQD parametresini içermesi, iki grup arasındaki benzerliği artırmıș olabilmektedir. Grup 1'e en az benzeyen ise anlamlılık seviyesine göre (0.289) grup 4 (Read vd., 1999) olmuștur. Ortalama farklılığı açısından grup 1'e en yakın gruplar; grup 5 (Barton, 2002) ve grup 6 (Zhang ve Einstein, 2004) olduğu ortaya çıkmıștır. Diğer gruplar kendi aralarında değerlendirildiğinde grup 4 (Read vd., 1999) ve grup 6 (Zhang ve Einstein, 


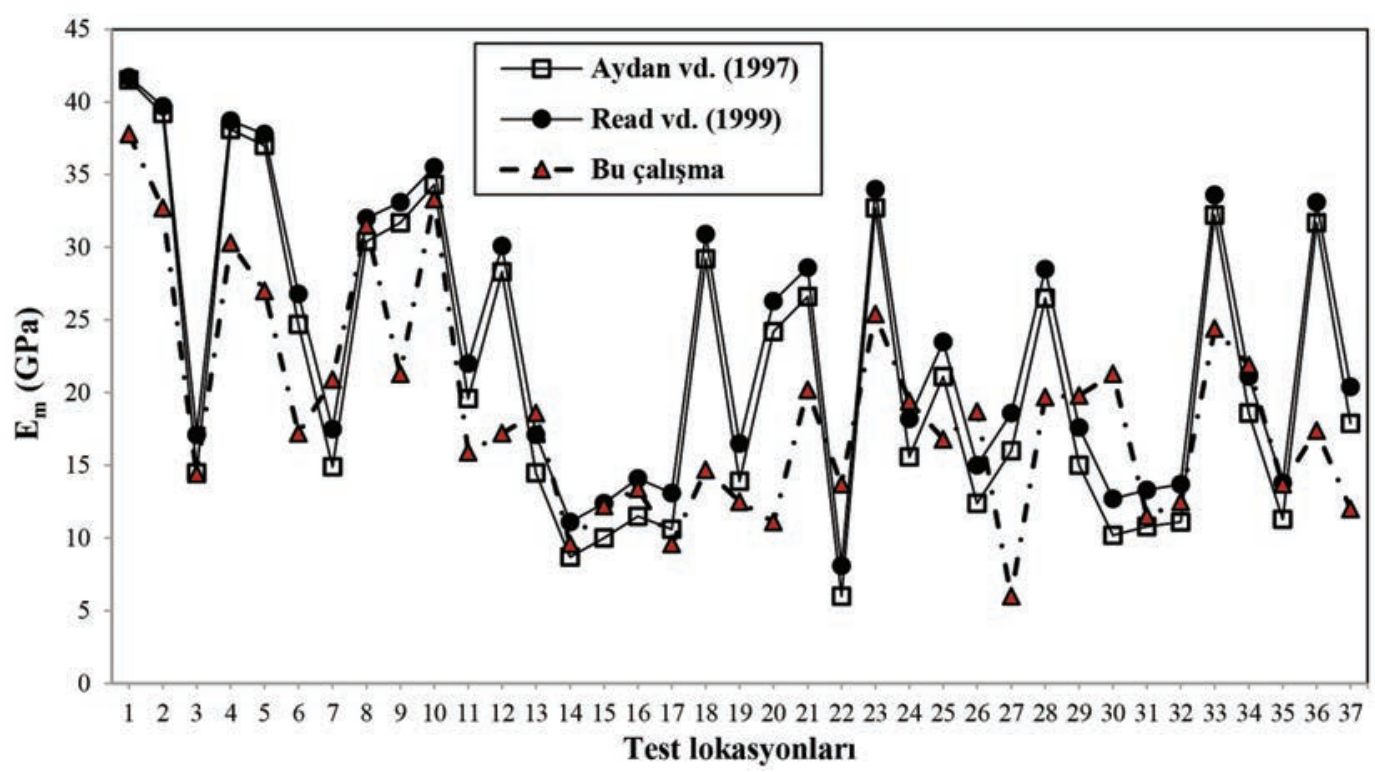

Șekil 6. $\mathrm{E}_{\mathrm{m}}$ değerlerinin karșılaștırılması

Figure 6. Comparison of $E_{m}$ values

2004) arasında fark olduğu anlașılmaktadır. Ancak bu çalıșmada grup 1 (önerilen eșitlik) ile diğer grupların benzerliği araștırımıștır. Gruplara ait en düșük, en yüksek ve ortalama değerleri gösteren grafik Șekil 8' de, buna ait sayısal bilgiler de Çizelge 6'da gösterilmiştir. Çizelge 5, 6 ve Șekil 8 incelendiğinde bu çalıșmada üretilen eșitliğin ANOVA çoklu karșılaștırma analizlerine göre güvenilir olduğu ortaya çıkmıștır. Ayrıca söz konusu eșitliğin diğerlerine göre (UCS, $E_{i}$ vb.) daha ucuz ve kolay elde edilebilen parametreleri (RQD ve Is $\left.{ }_{(50)}\right)$ içermesi, yüksek kaliteli karota intiyaç duymaması ve deneyin arazide yapılabilmesi gibi araștırmacıların ișini kolaylaștırması bakımından oldukça önemli olduğu düșünülmüștür.

\section{SONUÇLAR}

Bu çalıșmada 7132 metre uzunluğa sahip bir tünel güzergâhının 37 farklı aynasında süreksizlik özellikleri RMR ve $Q$ sınıflaması için belirlenmiștir. Aynı noktalardan alınan kaya blokları laboratuvara getirilerek karot örnekleri üzerinde deneyler yapılmıștır. Yapılan deney ve ölçümlerden așağıdaki sonuçlar elde edilmiștir.

1) RMR ve $Q$ kaya kütlesi sınıflama sisteminden, $R Q D$ ve $E_{i}$ parametrelerinden literatürde önerildiği șekliyle $E_{m}$ değerleri bulunmuștur. $E_{m}$ değerleri; Bieniawski (1978) eșitliği için en düșük 0.4 en yüksek $49.4 \mathrm{GPa}$, Aydan vd. (1997) eșitliği için en düșük 6.0 en yüksek $41.5 \mathrm{GPa}$, Read vd. (1999) eşitliği için en düşük 8.1 en yüksek $41.7 \mathrm{GPa}$, Barton (2002) eșitliği için en düșük 11.6 en yüksek 30.8 GPa ve Zhang ve Einstein (2004) eșitliği için en düșük 3.8 en yüksek $42.1 \mathrm{GPa}$ olarak bulunmuștur.

2) Bu çalıșma kapsamında literatürdeki diğer eșitliklere göre uygulaması daha kolay olan, $E_{m}$ değerlerinin pratik olarak belirlemeye yönelik bir eșitlik üretilmiștir. Önerilen eșitliğin daha ucuz ve kolay elde edilebilen parametreleri (RQD ve Is $\left.{ }_{(50)}\right)$ içermesi, yüksek kaliteli karota intiyaç duymaması ve deneyin arazide yapılabilmesi gibi araștırmacıların ișini kolaylaștırması bakımından oldukça önemli olduğu düșünülmüștür. $\mathrm{E}_{\mathrm{m}}$ değerleri; söz konusu eșitlik için en düșük 6 en yüksek 37.8 $\mathrm{GPa}$ olarak bulunmuștur.

3) Bu çalıșmada önerilen ve daha önce önerilmiș eșitlikler ANOVA çoklu karșılaștırma analizleri ile karșılaștırımıștır. ANOVA analizleri bu çalıșmada üretilen eșitliğin kaya kütlelerinin $E_{m}$ değerlerinin belirlenmesinde güvenle kullanılabileceğini göstermiștir. Ancak unutulmamalıdır ki; ampirik eşitlikleri tek başına kullanmak yerine farklı parametreleri içeren eşitlikler ile birlikte kullanmak ve bulguları 

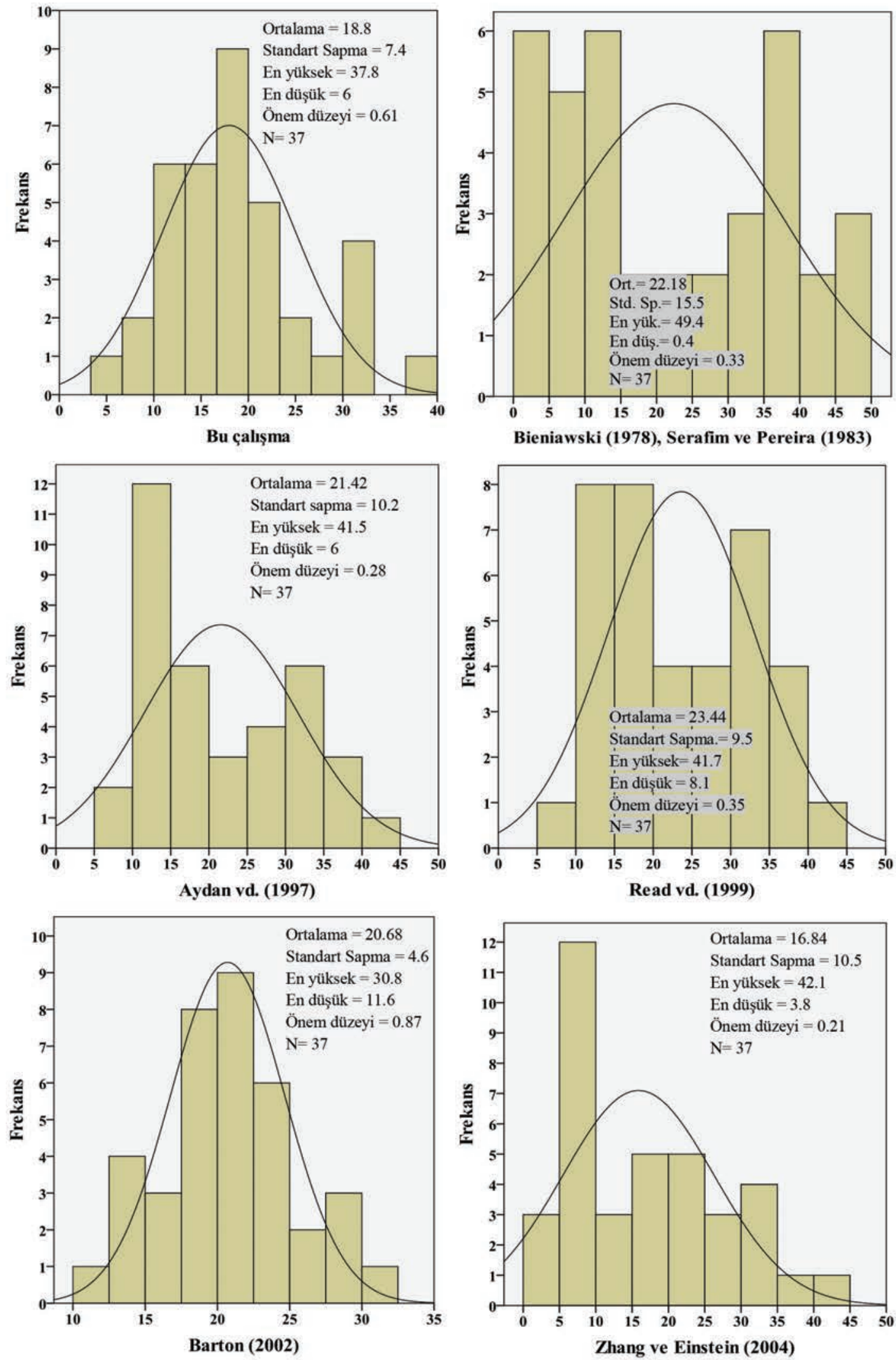

Șekil 7. Deformasyon modülü değerlerinin histogram grafikleri

Figure 7. Histogram charts of deformation modulus values 
Çizelge 5.Grupların çoklu karșılaștırması (ANOVA Tamhane's T2 testi) Table 5. Multiple comparison of groups (ANOVA Tamhane's T2 test)

\begin{tabular}{|c|c|c|c|c|c|c|}
\hline \multirow{2}{*}{$\begin{array}{l}\text { (I) Faktör/ } \\
\text { Grup }\end{array}$} & \multirow{2}{*}{$\begin{array}{c}\text { (J) } \\
\text { Faktör/ } \\
\text { Grup }\end{array}$} & \multirow{2}{*}{$\begin{array}{l}\text { Ortalama farklılığı } \\
\qquad(I-J)\end{array}$} & \multirow[b]{2}{*}{ Standart hata } & \multirow{2}{*}{$\begin{array}{l}\text { Anlamlılık } \\
\text { seviyesi }\end{array}$} & \multicolumn{2}{|c|}{ 95\% Güven aralığı } \\
\hline & & & & & Alt sınıf & Üst sınır \\
\hline \multirow{5}{*}{1} & 2 & -3.3838 & 2.8259 & 0.983 & -12.058 & 5.290 \\
\hline & 3 & -2.6189 & 2.0688 & 0.971 & -8.903 & 3.666 \\
\hline & 4 & -4.6405 & 1.9868 & 0.289 & -10.669 & 1.388 \\
\hline & 5 & -1.8784 & 1.4359 & 0.962 & -6.256 & 2.499 \\
\hline & 6 & 1.9595 & 2.1145 & 0.999 & -4.468 & 8.387 \\
\hline
\end{tabular}

1: Bu çalıșma, 2: Bieniawski (1978), Serafim ve Pereira (1983), 3: Aydan vd. (1997), 4: Read vd. (1999),

5: Barton (2002), 6: Zhang ve Einstein (2004).

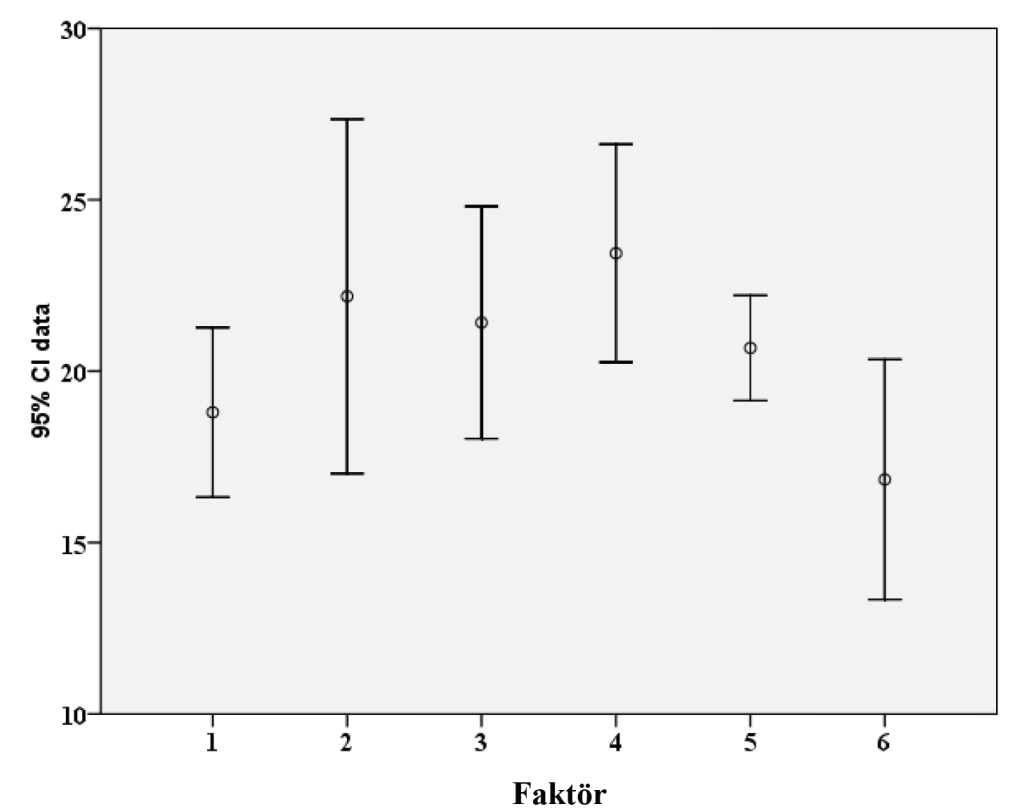

Șekil 8. Farklı metotlardan elde edilen $\mathrm{E}_{\mathrm{m}}$ değerlerine ait ortalamaların karșılaștıııması

Figure 8. Comparison of the mean values of $E_{m}$ obtained from different methods

Çizelge 6. Grupların istatistiksel değerleri

Table 6. Statistical values of the groups

\begin{tabular}{|c|c|c|c|c|c|c|}
\hline Gruplar & $\mathbf{N}$ & Ortalama & Standart sapma & Standart hata & $\begin{array}{l}\text { En düșük } \\
E_{m}, G P a\end{array}$ & $\begin{array}{c}\text { En yüksek } \\
E_{m}, G P a\end{array}$ \\
\hline 1 & 37 & 18.800 & 7.4210 & 1.2200 & 6.0 & 37.8 \\
\hline 2 & 37 & 22.184 & 15.5050 & 2.5490 & 0.4 & 49.4 \\
\hline 3 & 37 & 21.419 & 10.1627 & 1.6707 & 6.0 & 41.5 \\
\hline 4 & 37 & 23.441 & 9.5381 & 1.5681 & 8.1 & 41.7 \\
\hline 5 & 37 & 20.678 & 4.6060 & 0.7572 & 11.6 & 30.8 \\
\hline 6 & 37 & 16.841 & 10.5056 & 1.7271 & 3.8 & 42.1 \\
\hline Toplam & 222 & 20.560 & 10.2957 & 0.6910 & 0.4 & 49.4 \\
\hline
\end{tabular}

N: Veri sayısı, 1: Bu çalıșma, 2: Bieniawski (1978), Serafim ve Pereira (1983), 3: Aydan vd. (1997), 4: Read vd. (1999), 5: Barton (2002), 6: Zhang ve Einstein (2004). 
arazi gözlemleri ile birlikte değerlendirmek, araştırmacıları daha doğru bir sonuca götürecektir. Önerilen eșitlik kaya kütlelerine ait deformasyon modülü hakkında bir fikir vereceğinden ön analizlerde ve güzergâh belirleme çalıșmalarında kullanımı önerilmiștir.

\section{KATKI BELIRTME}

Yazarlar, bu çalıșmanın yürütülmesine katkıda bulunan Enerjisa A.Ș'ye ve Karadeniz Teknik Üniversitesi Araștırma Fonuna (Proje no: 9706) teșekkür ederler.

\section{KAYNAKLAR}

Abad, J., Caleda, B., Chacon, E., Gutierrez, V., and Hidlgo, E., 1983. Application of geomechanical classification to predict the convergence of coal mine galleries and to design their supports. 5th International Society for Rock Mechanics Congress, Melbourne, 15-19.

Aksoy, C.A., Geniș, M., Aldaș, G.U., Özacar, V., Özer, S.C., and Yılmaz, Ö., 2012. A comparative study of the determination of rock mass deformation modulus by using different empirical approaches. Engineering Geology, 131-132, 19-28.

Aydan, Ö., Ulusay, R., and Kawamoto, T., 1997. Assessment of rock mass strength for underground excavations. Proceedings of the 36th US rock mechanics symposium, New York, June/July, 777-786.

Barton, N.R., Lien, R. and Lunde, J., 1974. Engineering Classification of Rock Masses for the Design of Tunnel Support. Rock Mechanics 6, 189-239.

Barton, N., 1995. The influence of joint properties in modelling jointed rock masses. Keynote Lecture, 8th Congress ISRM, Tokyo.

Barton, N.R., 2002. Some New Q-value Correlations to Assist in Site Characterization and Tunnel Design. International Journal of Rock Mechanics Mining Sciences 39 (2), 185-216.

Basarir, H., Ozsan, A. and Karakus, M., 2005. Analysis of support requirements for a shallow diversion tunnel at Guledar dam site, Turkey. Engineering Geology 81(2), 131-145.

Bieniawski, Z.T., 1973. Engineering classification of jointed rock masses. Transactions of the South African Institute of Civil Engineers, 15 (12), 335-344.

Bieniawski, Z.T., 1976. Rock mass classification in rock engineering applications. Proceedings of the Symposium on Exploration for Rock Engineering, South Africa, Balkema, Rotterdam, 97-106.

Bieniawski, Z.T., 1978, Determining rock mass deformability, experience from case histories. International Journal of Rock Mechanics and Mining Sciences \& Geomechanics Abstracts, 15 (5), 237-247.

Bieniawski, Z.T., 1989. Engineering rock mass classifications, Wiley, New York, 251.

Chun, B., Lee, Y., Seo, D., and Lim, B., 2006. Correlation of deformation modulus by PMT with RMR and rock mass condition. Tunnelling and Underground Space Technol., 21 (3-4): 231-232.

Clerici, A., 1993. Indirect determination of rock masses-case histories. L.M. Riberio e Sousa and N.F. Grossman, eds. Proceedings of the Symposium EUROCK'93. Rotterdam: AA Balkema, 509-517.

Deere, D. U., 1964. Technical description of rock cores for engineering purposed, Rock Mechanics and Rock Engineering, 1, 17-22.

Geniș, M., Basarir, H., Ozarslan, A., Bilir, E. and Balaban, E., 2007. Engineering geological appraisal of the rockmasses and preliminary support design, Dorukhan Tunnel, Zonguldak, Turkey. Engineering Geology, 92, 14-26.

Gürocak, Z., 2011. Analyses of stability and support design for a diversion tunnel at the Kapikaya dam site, Turkey. Bulletin of Engineering Geology and the Environment, 70 (1), 41-52.

Gökçeoğlu, C., Sönmez, H. and Kayabașı, A., 2003. Predicting the deformation moduli of rock masses. International 
Journal of Rock Mechanics Mining Sciences, 40, 701-710.

Hashemi, M., Moghaddas, S., and Ajalloeian, R., 2010. Application of rock mass characterization for determining the mechanical properties of rock mass: a comparative study. Rock Mechanics and Rock Engineering, 43, 305-320

Hochberg, Y., and Tamhane, A.C., 1987. Multiple comparison procedures. New York: John Wiley \& Sons press.

Hoek, E., and Brown, E.T., 1997. Practical estimates of rock mass strength. International Journal of Rock Mechanics Mining Sciences, 34 (8), 1165-1186.

Hoek, E., and Diederichs, M.S., 2006. Empirical estimation of rock mass modulus. International Journal of Rock Mechanics Mining Sciences, 43, 203-215.

ISRM., 1981. ISRM Suggested Methods: Rock Characterization, Testing and Monitoring, E. T. Brown (ed.), Pergamon Press, London.

ISRM., 2007. The complete ISRM suggested methods for rock characterization, testing and monitoring: 1974-2006. In: Ulusay, Hudson (Eds.), Suggested methods prepared by the commission on testing methods, International Society for Rock Mechanics. ISRM Turkish National Group, Ankara, Turkey.

Ișık, N., S., Ulusay, R., and Doyuran, V., 2008. Deformation Modulus of Heavily Jointed-Sheared and Blocky Greywackes by Pressuremeter Tests: Numerical, Experimental and Empirical Assessments, Engineering Geology, 101, 269-282.

Kahraman, S., 2001. Evaluation of simple methods for assessing the uniaxial compressive strength of rock. International Journal of Rock Mechanics Mining Sciences, 38, 981-994.

Kaiser, T.K., and Gale, A.D., 1985. Evaluation of Cost and Emprical Support Design at B.C. Rail Tumbler Ridge Tunnels. Canadian Tunnelling, Tunnelling Association of Canada, Wiley, New York, 77-106.
Karaman, K., and Kesimal, A., 2013. Evaluation of the influence of porosity on the Engineering properties of volcanic rocks from the Eastern Black Sea Region: NE Turkey. Arabian Journal of Geosciences, 1-8 .

Karaman, K., Kesimal, A., Kaya, A., and Demirel, S., 2013. Dolaylı yöntemlerle belirlenen kaya malzemesine ait tek eksenli basınç dayanımı parametresinin $\mathrm{RMR}_{89}$ puanı hesaplamalarında kullanılabilirliği, 3. Uluslararası Ulașımda Yeraltı Kazıları Sempozyumu, 29-30 Kasım, İstanbul.

Karaman, K., Kesimal, A., and Ersoy, H., 2014. A comparative assessment of indirect methods for estimating the uniaxial compressive and tensile strength of rocks. Arabian Journal of Geosciences, 1-11.

Karslı, M., 2009. Arhavi-Hopa (Artvin) arasındaki karayolu șevlerinin duraylılık açısından incelenmesi, Karadeniz Teknik Üniversitesi, Fen Bilimleri Enstitüsü, Yüksek Lisans Tezi, Trabzon.

Kaya, A., Bulut, F., Alemdağ, S., and Sayın, A., 2011. Analysis of support requirements for a tunnel portal in weak rock: A case study from Turkey. Scientific Research and Essays, 6 (31), 6566-6583.

Kaya, A., 2012. Cankurtaran (Hopa-Artvin) tünel güzergahının ve çevresinin jeoteknik açıdan incelenmesi. Karadeniz Teknik Üniversitesi Fen Bilimleri Enstitüsü, Doktora Tezi, 185 pp.

Kayabașı, A., Gokceoglu, C., and Ercanoglu, M., 2003. Estimating the deformation modulus of rock masses: a comparative study. International Journal of Rock Mechanics Mining Sciences, 40, 55-63.

Ketin, i.., 1966. Tectonic units of Anatolia. Bull. Mineral Researh and Exploration Institu of Turkey, 66, 22-34.

Khabbazi, A., Ghafoori, M., Lashkaripour, G.R., and Cheshomi, A., 2013. Estimation of the rock mass deformation modulus using a rock classification system. Geomechanics and Geoengineering: An international Journal, 46-52, 8/1. 
Kumar, N., Samadhiya, N.K., Anbalagan, R., 2004. Application of rock mass classification system for tunneling in Himalaya, India Paper 3B 14, SINOROCK2004 Symposium. International Journal of Rock Mechanics Mining Sciences, 41 (3), 531.

Nejati, H.R., Ghazvinian, A., Moosavi, S.A., and Sarfarazi, V., 2014. On the use of the RMR system for estimation of rock mass deformation modulus. Bulletin of Engineering Geology and the Environment, 73 (2), 531-540.

Laderian, A., and Abaspoor, M.A., 2012. The correlation between RMR and $Q$ systems in parts of Iran. Tunnelling Underground Space Technology, 27, 149158.

Ocak, I., 2008. Estimating the modulus of elasticity of the rock material from compressive strength and unit weight. Journal of the South African Institute Mining and Metallurgy, 108 (10), 621-626.

Özdamar, K., 2011. Paket programlar ile istatistiksel veri analizi. Kaan Kitabevi, Eskișehir, 8. Baskı.

Palmström, A., and Singh, R., 2001. The deformation modulus of rock masses-comparisons between in situ tests and indirect estimates. Tunnelling Underground Space Technology, 16, 115-131.

Priest, S., D. and Hudson, J.A., 1976. Discontinuity spacing in rock, International Journal of Rock Mechanics and Mining Sciences and Geomechanics, Abstracts, 13, 135-148.

Ramamurthy, T., 2004. A geo-engineering classification for rocks and rock masses. International Journal of Rock Mechanics Mining Sciences, 41, 89-101.

Read, S.A.L., Richards, L.R., and Perrin, N.D., 1999. Applicability of the Hoek-Brown failure criterion to New Zealand greywacke rocks, Proc. 9th International Congress on Rock Mechanics, Paris, 2, 655-660.

Sarı, D., and Pasamehmetoglu, A.G., 2004. Proposed support design, Kaletepe tunnel,
Turkey, Engineering Geology, 72, 201216.

Serafim, J.L., and Pereira, J.P., 1983. Consideration of the geomechanics classification of Bieniawski, Proceedings of the International Symposium on Enginering Geology Underground Construction, Lisbon, Portugal, 1133-1144.

Shen, J., Karakus, M., and Chaoshui, X., 2012. A comparative study for empirical equations in estimating deformation modulus of rock masses. Tunnelling Underground Space Technology, 32, 245-250.

Singh, T.N., Kainthola, A., and Venkatesh, A., 2012. Correlation between point load index and uniaxial compressive strength for different rock types. Rock Mechanics and Rock Engineering 45 (2), 259-264.

Sönmez, H., Gökçeoğlu, C., Nefeslioğlu, H.A., and Kayabaşı, A., 2006. Estimation of rock modulus: for intact rocks with an artificial neural network and for rock masses with a new empirical equation. International Journal of Rock Mechanics and Mining Sciences, 43, 224-235.

Terzaghi, K., 1946. Rock Defects and Loads on Tunnel Support. In: Proctor, R. V., White $T$ (eds), Rock Tunnelling with Steel Support, 1. Commercial Shearing Co., Youngstown, $\mathrm{OH}, 15-99$.

Tuğrul, A., 1998. The application of rock mass classification systems to underground excavation in weak limestone, Atatürk dam, Turkey. Engineering Geology, 50 (3-4), 337-345.

Ulusay, R., and Sönmez, H., 2007. Kaya Kütlelerinin Mühendislik Özellikleri, 2. Baskı, Jeoloji Mühendisleri Odası, Ankara.

Zhang, L., and Einstein, H.H., 2004. Using RQD to estimate the deformation modulus of rock masses. International Journal of Rock Mechanics and Mining Sciences, 41 (2), 337-41.

Zhang, L., 2004. Drilled Shafts in Rock Analysis and Design. A. A. Balkema Publishers, Taylor \& Francis Group Plc., London, UK. 